\title{
PERAN PEMERINTAH DALAM MENGUPAYAKAN HAK ATAS UPAH YANG LAYAK BAGI PEKERJA (STUDI PADA DINAS TENAGA KERJA DAN PERINDUSTRIAN KOTA SURAKARTA).
}

Oleh :

\author{
Wulandari, Triana Rejekiningsih, Muh. Hendri Nuryadi \\ Program Studi PPKn FKIP Universitas Sebelas Maret Surakarta \\ e-mail: wulandari21@student.uns.ac.id
}

\begin{abstract}
This research has aims to know: 1) employee's, entrepreneur's, and government's perception about proper payment, 2) Government's role, labor offices and industrial, strives for proper payment, 3) problem and government's problem solve to strive proper payment.

This research used qualitative research method with purposive sampling technique. Data collecting technique which is used are observation, interview and documentation. Trustworthiness of the Data which is used is source of the data triangulation and triangulation method. The data analysis of the research used interactive analysis method.

The results of the research show that: 1) there are some of differences perception between employee, entrepreneur, and government on proper payment. Employees have a hunch that proper payment is payment which appropriate with their requirement. According to entrepreneur's point of view, proper payment is payment which is agreed by both of employees and entrepreneur. Whereas, according to government's proper payment is payment which appropriate with requirement based on KHL calculation. 2) Surakarta Labor Offices and industrial's role about minimum payment are; a) payment minimum calculation, $b$ ) suggesting to Regent or Mayor, c) doing monitoring, d) giving punishment. Whereas in the principal structure and payment scale; a) giving training and socialization, b) doing monitoring, c) giving punishment. 3) problems ; a) entrepreneur's less understanding about structure and payment scale, b)there is entrepreneur which is burdened and do not arrange the structure and payment scale. Problem solutions; a) giving socialization and training to entrepreneur, b) giving administration punishment to the entrepreneur which do not arrange the structure and payment scale.
\end{abstract}

Keywords: authority, payment, employees, labor offices and industrial. 


\begin{abstract}
ABSTRAK
Penelitian ini bertujuan untuk mengetahui: 1) persepsi pekerja, pengusaha, dan pemerintah mengenai upah yang layak; 2) peran pemerintah yaitu Dinas Tenaga Kerja dan Perindustrian Kota Surakarta dalam mengupayakan hak atas upah yang layak; 3) Hambatan dan solusi pemerintah dalam mengupayakan upah yang layak bagi pekerja.

Penelitian ini menggunakan metode penelitian kualitatif dengan tekhnik purposive sampling. Pengumpulan data menggunakan observasi, wawancara dan dokumentasi. Pengujian validitas data menggunakan trianggulasi sumber data dan trianggulasi metode. Analisis data menggunakan model analisis interaktif.

Hasil penelitian menunjukkan bahwa: 1) Terdapat perbedaan persepsi antara pekerja, pengusaha, dan pemerintah mengenai upah yang layak. Pekerja beranggapan bahwa upah yang layak adalah upah yang sesuai dengan kebutuhan pekerja. Menurut pengusaha, upah yang layak adalah upah yang disetujui oleh kedua belah pihak. Sedangkan menurut pemerintah, upah yang layak adalah upah yang sesuai dengan kebutuhan berdasarkan perhitungan KHL. 2) Peran Dinas Tenaga Kerja dan Perindustrian Kota Surakarta mengenai kebijakan upah minimum adalah: a) perhitungan upah minimum, b) mengusulkan ke Bupati/Walikota, c) melakukan pengawasan, d) memberikan sanksi. Sedangkan dalam kebijakan struktur dan skala upah yaitu: a) memberikan pelatihan dan sosialisasi, b) melakukan pemantauan dan monitoring, c) memberikan sanksi. 3) Hambatan: a) kurangnya pemahaman pengusaha mengenai struktur dan skala upah, b) ada pengusaha yang merasa terbebani dan tidak menyusun struktur dan skala upah. Solusi: a) memberikan sosialisasi dan pelatihan kepada pengusaha, b) memberikan sanksi administratif kepada pengusaha yang tidak menyusun struktur dan skala upah.
\end{abstract}

Kata kunci: hak, upah, pekerja, Dinas Tenaga Kerja dan Perindustrian. 


\section{PENDAHULUAN}

Hak Asasi Manusia (HAM) adalah hak dasar yang dimiliki manusia sejak lahir dan merupakan anugrah dari Tuhan Yang Maha Esa. Di Indonesia pengaturan mengenai Hak Asasi Manusia (HAM) secara tegas diatur dalam Undang Undang No. 39 tahun 1999 tentang Hak Asasi Manusia. Menurut pasal 1 ayat (1) Undang-Undang Nomor 39 tahun 1999, "Hak Asasi Manusia adalah seperangkat hak yang melekat pada hakikat dan keberadaan manusia sebagai mahkluk Tuhan Yang Maha Esa dan merupakan Anugrah-Nya yang wajib dihormati, dijunjung tinggi dan dilindungi oleh negara, hukum, dan pemerintah, dan setiap orang demi kehormatan serta perlindungan harkat dan martabat manusia". Selanjutnya dalam pasal 2 "Negara Republik Indonesia mengakui dan menjunjung tinggi hak asasi manusia dan kebebasan dasar manusia sebagai hak yang secara kodrati melekat pada dan tidak terpisahkan dari manusia, yang harus dilindungi, dihormati, dan ditegakkan demi peningkatan martabat kemanusiaan, kesejahteraan, kebahagiaan, dan kecerdasan serta keadilan". Selain itu dalam UndangUndang Dasar Negara Republik Indonesia terdapat pengaturan mengenai HAM. Salah satu Hak Asasi Manusia yang dilindungi oleh Indonesia adalah hak untuk mendapat pekerjaan dan memperoleh kehidupan yang layak. Setiap orang melakukan suatu pekerjaan untuk mendapatkan upah, upah tersebut digunakan pekerja untuk memenuhi kebutuhannya sehingga dapat memperoleh kehidupan yang layak. Mendapat upah yang layak merupakan hak bagi setiap pekerja, karena dengan upah tersebut pekerja dapat memenuhi kebutuhan hidupnya dan keluarganya untuk meningkatkan kesejahterannya. Pekerja merupakan warga negara yang mempunyai hak untuk dapat hidup dengan layak. Hal ini sesuai dengan Pasal 27 ayat (2) UUD Negara Republik Indonesia Tahun 1945 bahwa "tiap-tiap warga negara berhak atas pekerjaan dan penghidupan yang layak bagi kemanusiaan" dan Pasal 28D ayat (2) UUD 1945 "Setiap orang berhak untuk bekerja serta mendapat imbalan dan perlakuan yang adil dan layak dalam hubungan kerja". Mendapat upah dan kehidupan yang layak merupakan hak asasi setiap manusia. Di Indonesia hal tersebut diatur dalam pasal 38 ayat (4) UndangUndang Nomor 39 Tahun 1999 tentang Hak Asasi Manusia, "Setiap orang baik pria maupun wanita dalam melakukan pekerjaan yang sepadan dengan martabat kemanusiaannya berhak atas upah yang adil sesuai prestasinya dan dapat menjamin kelangsungan kehidupan keluarganya." Serta dalam pasal 40 yang berbunyi "Setiap orang berhak untuk bertempat tinggal serta berkehidupan yang layak". Mendapatkan pekerjaan agar memperoleh upah atau imbalan agar dapat memiliki kehidupan yang layak 
merupakan hak warga negara dan hak asasi setiap manusia yang harus diupayakan oleh negara.

Berdasarkan pasal 1 ayat (30) Undang-Undang Nomor 13 Tahun 2003 tentang Ketenagakerjaan, upah merupakan hak pekerja/buruh yang ditetapkan dan dibayarkan menurut suatu perjanjian kerja, kesepakatan, atau peraturan perundang-undangan, termasuk tunjangan bagi pekerja/buruh dan keluarganya atas suatu pekerjaan dan atau jasa yang telah atau akan dilakukan. Pada pengertian tersebut maka tersirat makna bahwa upah ditetapkan salah satunya melalui perundang-undangan, maka yang dimaksud adalah upah minimum. Selanjutnya pada Pasal 88 ayat (2) dinyatakan bahwa untuk mewujudkan penghasilan yang memenuhi kebutuhan hidup yang layak bagi kemanusiaan pemerintah menetapkan kebijakan pengupahan yang melindungi pekerja. Kebijakan pengupahan merupakan salah satu wujud upaya perlindungan negara terhadap pekerja dalam mewujudkan penghasilan yang memenuhi penghidupan yang layak bagi kemanusiaan.

Penetapan upah minimum dimaksudkan agar pekerja/buruh terhindar dari kesewenang-wenangan pengusaha dalam pembayaran upah, atau hanya menjadi tujuan bisnis semata. Penetapan Upah minimum merupakan intervensi negara dalam memberikan perlindungan terhadap hak pekerja. Upah minimum ditetapkan oleh Gubernur dengan melibatkan pekerja dan pengusaha yang dikerangkakan dalam lembaga tripatrit (dewan pengupahan). Upah minimum ditetapkan dengan memperhatikan rekomendasi Dewan Pengupahan Provinsi dan atau Bupati/ Walikota.

Pemerintah Indonesia, melalui Undang-Undang Nomor 13 Tahun 2003 sudah mengatur bahwa kebutuhan hidup layak (KHL) menjadi faktor utama yang terang dan tegas dalam proses penetapan upah minimum. KHL ini disusun secara teknis melalui mekanisme yang diatur dalam Permenakertrans Nomor 13 Tahun 2012 tentang Kebutuhan Hidup Layak yang dilaksanakan oleh lembaga tripatrit yakni Dewan Pengupahan yang tersusun dari pemerintah, pengusaha, dan pekerja/buruh dengan melibatkan Badan Pusat Statistik setempat. Dewan Pengupahan ini bertugas untuk mengadakan survei dan menyusun nilai KHL yang nantinya diperlukan dalam penetapan upah minimum (baik UMK maupun UMP) oleh Gubernur. KHL ini adalah pokok utama dalam penetapan upah minimum. Dalam penetapan Upah Minimum Gubernur memperhatikan saran dan pertimbangan Dewan Pengupahan Provinsi dan rekomendasi Bupati/Walikota (Pasal 6 Permenakertrans Nomor 13 Tahun 2012).

Berdasarkan Keputusan

Gubernur Nomor 560/94 Tahun 2017 
tertanggal 20 November 2017 tentang Upah Minimum Pada 35 (Tiga Puluh Lima) Kabupaten/ Kota di Provinsi Jawa Tengah Tahun 2018, UMK Kota Surakarta mengalami kenaikan sekitar 8\% dari UMK Solo 2017, yaitu dari Rp1.534.985 menjadi Rp1.668.700. Besaran kenaikan UMK Kota Surakarta sesuai dengan usulan dari Dewan Pengupahan Kota Surakarta, yang sebelumnya telah disampaikan kepada Gubernur melalui Walikota Surakarta. Dewan Pengupahan menggunakan Peraturan Pemerintah (PP) No. 78/2015 tentang Pengupahan Murni dalam Penepatan UMK. Perhitungan usulan UMK Kota Surakarta menggunakan rumus UMK tahun berjalan ditambah inflasi nasional (September 2016-September 2017) sebesar 3,72\% ditambah pertumbuhan ekonomi nasional (September 2016-September 2017) sebesar 4,99\%. Dengan demikian, usulan UMK Kota Surakarta 2018 ditetapkan dari perhitungan Rp1.534.985 ditambah 8,71\% atau Rp133.697 menjadi Rp1.668.682. Lalu angka tersebut dibulatkan ke atas menjadi Rp1.668.700 sesuai kesepakatan Dewan Pengupahan. (http://disnakerperin.surakarta.go.id/d etail/berita-pasar-kerja-

surakarta/78/umk-kota-surakartatahun-2018.html diakses pada tanggal 14 April 2018 pukul 09.18 WIB)

Berdasarkan hasil observasi yang dilakukan pada tanggal 21 Mei 2018 di PT. Triangga Dewi, penulis mewawancarai beberapa pekerja.
Menurut wawancara yang penulis lakukan, pabrik tersebut sudah menerapkan UMK yang terbaru yaitu Rp1.668.682. Namun, masih ada pekerja yang mempunyai pinjaman atau hutang kepada orang lain untuk memenuhi kebutuhannya, dikarenakan memang kebutuhan hidupnya yang cukup besar dan juga harga barangbarang yang sekarang ini naik. Beberapa pekerja mengeluhkan harga barang-barang saat ini yang naik secara terus-menerus. Hal tersebut tentu saja mempersulit pekerja untuk memenuhi kebutuhannya. Terlebih lagi ketika pekerja tersebut sudah berkeluarga dan mempunyai anak, tentunya pengeluaran yang dikeluarkannya akan bertambah, bukan hanya membeli barang kebutuhan pokok tetapi membeli barang kebutuhan yang lain dan untuk biaya sekolah. Untuk memenuhi kebutuhan hidupnya dengan UMK yang sekarang, semua pekerja yang penulis wawancara mengatakan "dicukup-cukupkan". Hal tersebut berarti dengan kenaikan UMK yang sekarang ini, masih ada kebutuhan pekerja yang sulit untuk dipenuhi.

Kenaikan UMK tahun 2018 tidak melalui survei KHL karena berdasarkan peraturan perundangundangan yang berlaku, survei KHL dilakukan satu kali dalam lima tahun. Survei KHL terakhir dilaksanakan pada tahun 2014, dan selanjutnya akan dilaksanakan pada tahun 2019. Dengan tidak adanya survei KHL, penetapan upah pada tahun ini akan 
mengacu pada Peraturan Pemerintah (PP) Nomor 78 tahun 2015 tentang pengupahan.

Pemberlakuan PP Nomor 78 tahun 2015 tersebut mendapat penolakan dari kaum buruh. seperti yang terjadi di Jakarta. Penetapan kenaikan Upah Minimum Provinsi (UMP) DKI Jakarta 2018 sebesar $8,17 \%$ mendapat penolakan dari Asosiasi Serikat Pekerja (Aspek). Mereka meminta hasil survei Kebutuhan Hidup Layak (KHL) dimasukkan dalam unsur perhitungan kenaikan UMP. Menurut Mirah Sumirat "Survei KHL tidak dilakukan karena PP 78 Tahun 2015, tidak menuliskan itu, sehingga upah buruh makin tergerus," kata dia kepada Okezone. Mirah melanjutkan, perwujudan PP 78 Tahun 2015 sangat bertentangan dengan Undang-undang Nomor 13 tahun 2003 tentang ketenagakerjaan pasal pengupahan. Dimana dalam penetapan upah minimum, seharusnya ditetapkan dalam tiga unsur, meliputi pengusaha, serikat pekerja, dan juga pemerintah. Oleh karena itu, menurut Mirah, formulasi sekarang kurang mewakili kondisi kaum buruh. "Bukan kami enggak percaya, tapi kalau berdasarkan inflasi saja tidak menguatkan, jadi memang harus ada survei. Kalau secara survei adalah perhitungan secara nyata. Berapa kenaikan harga kebutuhan pokok di pasar, kemudian dihitung bersama dengan inflasi dan pertumbuhan ekonomi itu baru fair," tukas dia. (https://economy.okezone.com/read/2 017/11/02/320/1807423/ump-cumanaik-8-17-buruh-minta-komponenkebutuhan-hidup-layak-ikutdiperhitungkan diakses pada tanggal 20 Oktober 2018 pukul 14.08 WIB)

Selain itu, kenaikan UMK kota Surakarta pada tahun 2018 dinilai kurang apabila dihitung berdasarkan perhitungan KHL. Menurut Hudi Wasisto (ketua Serikat Pekerja Nasional Surakarta) kenaikan UMK Surakarta belum rasional. UMK harusnya naik 10 hingga 12 persen jika dihitung berdasarkan nilai KHL. Hal ini dikarenakan adanya kenaikan tarif dasar listrik, PDAM, dan harga beras. (http://solo.tribunnews.com/2017/10/ 31/nilai-umk-solo-2018-naik-jadi-rp1668700-serikat-pekerja-sebutjumlahnya-tak-rasional diakses pada tanggal 14 April 2018 pukul 09.53 WIB)

Sesuai dalam PP Nomor 78 Tahun 2015 pasal 41 ayat (1) disebutkan bahwa "Gubernur menetapkan upah minimum sebagai jaring pengaman". Artinya, pemerintah memiliki kewajiban dalam menetapkan upah minimum untuk melindungi pekerja dari eksploitasi pengusaha agar tercipta upah yang layak bagi pekerja. Hal tersebut berarti terdapat hubungan antara warga negara dengan negara dalam bentuk hak dan kewajiban. Warga negara memiliki hak dan kewajiban terhadap negara dan sebaliknya, negara memiliki hak dan kewajiban terhadap warganya. Artinya, sebagai warga 
negara maka ia memiliki hubungan timbal balik yang sederajat dengan negaranya (Winarno dan Wijianto, 2010: 28-29). Wujud hubungan antara negara dengan warga negara adalah pada umumnya berupa pernanan (role). Oleh karena itu negara memiliki peran terhadap pemenuhan hak bagi warga negara. Menurut TH Marshal (Freddy Kalidjernih, 2011: 5) kewarganegaraan

dikonseptualisasikan atas dasar tiga hak yaitu hak sipil, hal politik, dan hak sosial. Hak sipil mencakup perlindungan individu untuk bebas yaitu kebebasan berbicara, berkeyakinan, berhak atas keadilan. Hak politik mencakup hak berpartisipasi dalam pemerintahan. Hak sosial adalah hak untuk keamanan dan kesejahteraan, untuk berbagi dalam warisan sosial dan untuk hidup dalam kehidupan yang lebih maju sesuai dengan standar-standar yang berlaku dalam masyarakat. Oleh karena itu, pemerintah memiliki peranan untuk mengupayakan hak atas upah yang layak bagi pekerja. Penelitian ini dilakukan guna mengetahui peran pemerintah yaitu Dinas Tenaga Kerja dan Perindustrian Kota Surakarta dalam mengupayakan hak atas upah yang layak bagi pekerja.

\section{METODE PENELITIAN}

Penelitian ini merupakan penelitian deskriptif kualitatif. Deskriptif karena penelitian ini mengolah data objek penelitian berupa hasil wawancara dan data mengenai upah minimum untuk kemudian dianalisis dan interpretasi data. Kualitatif karena data yang digunakan tidak diperoleh melalui prosedurprosedur statistik, melainkan data berasal dari dokumen, catatan lapangan, naskah wawancara dan dokumen resmi lain. Menurut Denzin dan Lincon (1987) dalam Moleong (2014: 5) menyatakan bahwa "Penelitian kualitatif adalah penelitian yang menggunakan latar alamiah, dengan maksud menafsirkan fenomena yang terjadi dan dilakukan dengan jalan melibatkan berbagai metode yang ada".

Menurut H.B Sutopo (2002: 5054) "sumber data dalam penelitian kualitatif dapat berupa manusia, peristiwa, atau aktifitas, tempat atau lokasi, benda, beragam gambar, atau rekaman, dokumen atau arsip". Sumber data yang digunakan dalam penelitian ini adalah informan yang terdiri atas Kepala Seksi Perumusan Pengupahan dan Kesejahteraan Pekerja Dinas Tenaga Kerja dan Perindustrian Surakarta, Ketua Bidang Hukum Pengupahan dan Ketenagakerjaan APINDO Surakarta, Anggota Dewan Pengupahan Surakarta, pekerja di PT Trianggadewi Surakarta, pekerja Toko Listrik Sinar Dunia. Peneliti juga menggunakan sumber data tempat yaitu di Dinas Tenaga Kerja dan Perindustrian Kota Surakarta, APINDO Surakarta, PT Trianggadewi, dan Toko Listrik Sinar Dunia. Selain itu, peneliti juga menggunakan dokumen berupa peraturan perundang-undangan, tabel 
KHL, halaman web, foto kegiatan, dan data lain yang terkait.

Peneliti memilih teknik purposeful sampling dengan mengambil orang-orang kunci untuk dijadikan sebagai sumber data. Adapun informan kuci dalam penelitian ini yaitu, Kepala Seksi Perumusan Pengupahan dan Kesejahteraan Pekerja Dinas Tenaga Kerja dan Perindustrian Surakarta, Ketua Bidang Hukum Pengupahan dan Ketenagakerjaan APINDO Surakarta, Anggota Dewan Pengupahan Surakarta, pekerja di PT Trianggadewi Surakarta, pekerja Toko Listrik Sinar Dunia.

Penelitian ini menggunakan teknik pengumpulan data wawancara, observasi, dan analisis dokumen. Wawancara dilakukan kepada Kepala Seksi Perumusan Pengupahan dan Kesejahteraan Pekerja Dinas Tenaga Kerja dan Perindustrian Surakarta, Ketua Bidang Hukum Pengupahan dan Ketenagakerjaan APINDO Surakarta, Anggota Dewan Pengupahan Surakarta, pekerja di PT Trianggadewi Surakarta, pekerja Toko Listrik Sinar Dunia. Observasi digunakan untuk mengetahui hambatan dan solusi yang dilakukan. Sementara analisis dokumen yang digunakan berupa peraturan perundang-undangan, tabel KHL, halaman web, foto kegiatan, dan data lain yang terkait.

Penulis menggunakan trianggulasi data dan trianggulasi metode dalam mencari validitas data.
Sedangkan analisis data menggunakan model interaktif Miles dan Huberman dalam Afrizal (2015: 178) yang dilakukan dalam siklus yang terdiri dari tahap mereduksi data, menyajikan data, dan menarik kesimpulan. 


\section{HASIL PENELITIAN dan PEMBAHASAN \\ Pesrsepsi Pekerja, Pengusaha dan Pemerintah mengenai upah yang layak}

Berdasarkan hasil penelitian yang telah diuraikan di atas, maka dapat diketahui bahwa terdapat perbedaan persepsi mengenai upah yang layak antara pekerja, pengusaha, dan pemerintah. Pekerja beranggapan bahwa upah yang layak adalah upah yang sesuai dengan kebutuhan pekerja. Hal ini dikarenakan pekerja bekerja dengan tujuan utama untuk mendapatkan penghasilan. Penghasilan ini mereka gunakan untuk memenuhi kebutuhan hidupnya, sehingga dapat berkehidupan dengan layak. Oleh karena itu, pekerja selalu mengharapkan upah mereka naik atau bertambah. Dengan upah yang besar, maka pekerja dapat memenuhi kebutuhannya dengan cukup bahkan bisa lebih, sehingga taraf hidup atau kesejahteraan pekerja tersebut dapat meningkat.

Menurut pengusaha, upah yang layak adalah upah yang disetujui oleh kedua belah pihak yaitu pengusaha dan pekerja. Syarat sah suatu perjanjian kerja salah satunya adalah adanya kesepakatan kedua belah pihak yaitu pekerja dan pengusaha. Jadi apabila pekerja menyetujui suatu perjanjian kerja maka pekerja tersebut juga setuju isi perjanjian kerja tersebut yang memuat pekerjaan, upah dan perintah. Pengusaha menganggap bahwa pekerja yang telah bersepakat untuk melakukan hubungan kerja berarti menyepakati besaran upah yang akan diberikan. Oleh karena itu apabila upah tersebut telah disepakati oleh kedua belah pihak maka upah tersebut sudah dapat dikatakan upah yang layak.

Pengertian upah yang layak menurut pemerintah adalah upah yang sesuai dengan kebutuhan berdasarkan perhitungan KHL. KHL merupakan Kebutuhan hidup layak yang terdiri atas beberapa komponen, dimana seriap komponen terdiri atas beberapa jenis kebutuhan hidup. KHL adalah standar kebutuhan yang harus dipenuhi oleh seorang buruh lajang untuk dapat hidup layak baik secara fisik, non-fisik dan sosial, untuk kebutuhan 1 (satu) bulan, dan berlaku bagi buruh dengan masa kerja kurang dari 1 (satu) tahun. KHL tersebut disurvei setiap 5 tahun sekali. Upah yang sesuai dengan perhitungan KHL dapat menambah kesejahteraan pekerja.

Peran Pemerintah dalam mengupayakan hak atas upah yang layak bagi pekerja

Untuk menjamin agar pekerja mendapatkan upah yang layak, maka pemerintah menetapkan kebijakan pengupahan yaitu kebijakan upah minimum dan kebijakan struktur dan skala upah. Dalam kebijakan upah minimum, Dinas Tenaga Kerja dan perindustrian Kota Surakarta mempunyai peran, yaitu:

a. Perhitungan Upah Minimum; 
b. Mengusulkan Bupati/Walikota;

c. Melakukan Pengawasan;

d. Memberikan sanksi.

Disetiap kabupaten/kota

terdapat Dewan Pengupahan. Di Surakarta juga terdapat dewan pengupahan yang terdiri atas pemerintah (Dinas Tenaga Kerja Dan Perindustrian Kota Surakarta), dinas perdagangan, pengusaha (APINDO), pekerja (Serikat Pekerja), perguruan tinggi, dan pakar dari BPS. Sesuai dalam Asri Wijayanti (2010: 119) "Keanggotaan dewan pengupahan terdiri atas unsur pemerintah, organisasi pengusaha, serikat pekerja/buruh, perguruan tinggi, dan pakar". Dewan pengupahan ini lah yang melakukan perhitungan Upah minimum. Upah minimum dihitung menggunakan formula perhitungan upah minimum dalam pasal 44 Peraturan Pemerintah Nomor 78 Tahun 2015 yaitu UMn = UMt + $\{$ UMt x (Inflasit $+\% \Delta$ PDBt) $\}$, UMK tahun berjalan ditambah inflasi nasional dan ditambah pertumbuhan ekonomi nasional.

Setelah didapat besaran UMK, maka dewan pengupahan mengusulkan ke Bupati atau Walikota yang kemudian akan direkomendasikan ke Gubernur untuk ditetapkan. Setelah ditetapkan oleh Gubernur, maka Pemerintah khususnya Dinas Tenaga Kerja dan Perindustrian kota Surakarta melakukan pengawasan agar setiap perusahaan di kota Surakarta ini menjalankan Kebijakan Upah Minimum yang telah ditetapkan. Pengawasan dilakukan dengan mendatangi perusahaan-perusahaan di Surakarta. Pegawai yang bertugas melakukan pengawasan melihat dengan jalan memeriksa dan menyelidiki sendiri apakah ketentuanketentuan dalam perundang-undangan dilaksanakan dan jika tidak demikian, maka harus diambil tindakan-tindakan yang wajar dan tegas untuk menjamin pelaksanaannya, membantu baik buruh maupun pimpinan perusahaan dengan jalan memberi penjelasanpenjelasan teknis dan nasihat-nasihat yang mereka perlukan agar mereka menyelami apa yang dimintakan oleh peraturan dan bagaimana melaksanakannya, menyelidiki keadaan perburuhan dan mengumpulkan bahan yang diperlukan untuk menyusun perundang-undangan perburuhan dan penetapan kebijaksanaan pemerintah.

Apabila dalam pengawasan, terdapat perusahaan yang tidak menjalankan upah minimum, maka perusahaan tersebut dapat dikenai sanksi. Sanksi yang diberikan berupa sanksi administratif yaitu teguran, pembatasan kegiatan, penghentian sementara, dan pembekuan usaha.

Selanjutnya dalam kebijakan struktur dan skala upah, Dinas Tenaga Kerja dan Perindustrian Kota Surakarta, berperan sebagai:

a. Memberikan Pelatihan dan Sosialisasi mengenai Struktur dan Skala Upah; 
b. Melakukan Pemantauan dan Monitoring;

c. Memberikan sanksi.

Setelah ditetapkan kebijakan mengenai struktur dan skala upah, kemudian Dinas Tenaga Kerja dan Perindustrian kota Surakarta melakukan pelatihan dan sosialisasi. Pelatihan dan sosialisasi ini bertujuan untuk memberikan pelatihan dan pemahaman kepada pengusaha dalam penyusunan struktur dan skala upah. Memberikan pelatihan dan sosialisasi kepada pengusaha mengenai struktur dan skala upah merupakan salah satau pelayanan yang diberikan kepada pemerintah yaitu Dinas Tenaga kerja dan perindustrian Kota Surakarta setelah ditetapkannya kebijakan mengenai struktur dan skala upah.

Setelah itu Dinas Tenaga Kerja dan Perindustrian kota Surakarta melakukan pemantauan dan Monitoring keberjalanan struktur dan skala upah ini. Kegiatan ini dilakukan dengan mendatangi perusahaanperusahaan di kota Surakarta. Kegiatan ini bertujuan untuk memastikan agar pengusaha menyusun struktur dan skala upah dalam sistem penggajian pekerjanya. Kegiatan pemantauan dan monitoring ini sama seperti kegiatan pengawasan. Pemerintah berharap seluruh pengusaha mau menyusun struktur dan skala upah ini untuk meningkatkan kesejahteraan pekerjanya. Oleh karena itu struktur dan skala upah ini menjadi kewajiban bagi pengusaha untuk disusun.
Dengan begitu maka kewajiban ini harus diawasi oleh pemerintah agar dilaksanakan dengan sungguhsungguh.

Selanjutnya sebagai tindak lanjut dari kegiatan pemantauan dan monitoring, Dinas Tenaga kerja dan Perindustrian kota Surakarta akan memberikan sanksi bagi perusahaan yang sampai batas waktu yang ditentukan belum juga menyusun dan menerapkan struktur dan skala upah dalam penggajian pekerjanya. Sanksi yang diberikan berupa sanksi administratif yaitu teguran, pembatasan kegiatan, penghentian sementara, dan pembekuan usaha.

\section{Hambatan dan Solusi}

Hambatan yang dialami Dinas tenaga Kerja dan Perindustrian Kota Surakarta dalam melaksanakan perannya mengupayakan hak atas upah yang layak bagi pekerja adalah:

a. Kurangnya pemahaman pengusaha mengenai struktur dan skala upah

Struktur dan skala upah ini merupakan kebijakan dari pemerintah untuk mengurangi kesenjangan antara upah terendah dengan upah tertinggi dalam suatu perusahaan. Dalam penyusunan struktur dan skala upah, pengusaha dapat melakukan 3 
tahapan, yaitu analisa jabatan, evaluasi jabatan dan penentuan struktur dan skala upah. Analisa jabatan yaitu proses memperoleh dan mengolah data jabatan setiap pekerja menjadi informasi jabatan yang dituangkan dalam bentuk uraian jabatan. Evaluasi jabatan yaitu proses menilai, membandingkan dan memeringkat jabatan. Setelah itu pengusaha menentukan struktur dan skala upah berdasarkan kemampuan perusahaan dan juga memperhatikan upah minimum. (Pasal 4 Peraturan Menteri Ketenagakerjaan Nomor 1 Tahun 2017 tentang Struktur dan Skala Upah)

Terdapat beberapa metode yang dapat digunakan pengusaha dalam penyusunan struktur dan skala upah, antara lain metode rangking sederhana, metode dua titik, dan metode poin faktor (Lampiran Peraturan Menteri Ketenagakerjaan Nomor 1 Tahun 2017). Penggunaan metode tersebut disesuaikan dengan kondisi perusahaan masing-masing.

Banyaknya tahap serta pekerja yang harus dihitung, membuat pengusaha menjadi bingung dan malah tidak paham dengan ketentuan dalam struktur dan skala upah ini. Akibatnya pengusaha kurang paham dan belum melakukan penyusunan struktur dan skala upah.

b. Ada perusahaan yang enggan untuk menyusun struktur dan skala upah.

Kebijakan struktur dan skala upah ini merupakan kebijakan dimana setiap pekerja mendapatkan upah berdasarkan kriteria tertentu sesuai yang dimiliki pekerja. Upah yang diberikan harus diatas upah minimum. Ketentuan tersebut terkadang membuat pengusaha keberatan, karena harus membayar pekerja diatas upah minimum sehingga pengeluaran yang harus dikeluarkan perusahaan menjadi semakin banyak. Sesuai dalam Zaeni Asyhadie (2015: 76) "bagi pengusaha, upah adalah biaya produksi yang harus ditekan serendah-rendahnya agar harga barangnya nanti tidak menjadi terlalu tinggi agar keuntungannya menjadi lebih tinggi". Terlebih lagi perusahaan dengan jumlah pekerja yang banyak, membuat pengusaha menjadi terbebani karena biaya yang dikeluarkan untuk memberikan upah ke pekerja menjadi semakin banyak. Oleh karena itu banyak perusahaan yang belum atau tidak menyusun struktur dan skala upah ini.

Dengan adanya hambatan tersebut, maka pemerintah melakukan langkah-langkah untuk menyelesaikan hambatan tersebut. Langkah-langkah tersebut yaitu:

a. Sosialisasi dan Pelatihan

Sebagai salah satu bentuk pelayanan pemerintah terhadap masyarakat, pemerintah yaitu Dinas Tenaga Kerja dan Perindutrian Kota Surakarta memberikan Sosialisasi dan Pelatihan kepada pengusaha mengenai cara penyusunan struktur dan skala upah. Kegiatan ini dilakukan sebagai solusi untuk mengatasi pengusaha yang tidak paham terhadap kebijakan sturktur dan skala upah. Dalam kegiatan ini, pengusaha diberikan 
pengajaran mengenai bagaimana menyusun struktur dan skala upah dan juga diberikan sosialisasi pentingnya menyusun struktur dan skala upah. Sehingga pengusaha tidak akan merasa dirugikan atau keberatan untuk memberikan upah yang lebih kepada pekerja. Kegiatan ini juga menghadirkan narasumber yang ahli dibidangnya, sehingga pengusaha dapat bertanya dan berkonsultasi secara langsung mengenai penyusunan struktur dan skala upah di perusahaanya.

b. Memberikan Sanksi administratif kepada perusahaan yang tidak menerapkan struktur dan skala upah.

Penyusunan struktur dan skala upah ini merupakan kewajiban bagi pengusaha dan sudah diatur dalam peraturan perundang-undangan. Oleh karena itu, perusahaan yang tidak menyusun struktur dan skala upah akan dikenai sanksi dari pemerintah. Sanksi yang diberikan kepada pengusaha yang sampai waktu yang diberikan tidak menyusun struktur dan skala upah berupa sanksi administratif. Menurut pasal 59 ayat 2 Peraturan Pemerintah Nomor 78 Tahun 2015, Sanksi administratif ini berupa:

1) Teguran tertulis

2) Pembatasan kegiatan usaha

3) Penghentian sementara sebagian atau seluruh alat produksi

4) Pembekuan kegiatan usaha Sanksi ini diberikan berdasarkan pemeriksaan yang dilakukan oleh pengawas ketenagakerjaan. Apabila dalam pengawasan terdapat perusahaan yang tidak menyusun struktur dan skala upah dan tidak memberitahukan kepada pekerja maka dapat dikenai sanksi. 


\section{SIMPULAN dan SARAN}

\section{Simpulan}

1. Pesrsepsi Pekerja, Pengusaha dan Pemerintah mengenai upah yang layak

Terdapat perbedaan persepsi antara pekerja, pengusaha dan pemerintah mengenai upah yang layak. Pekerja beranggapan bahwa upah yang layak adalah upah yang sesuai dengan kebutuhan pekerja. Menurut pengusaha, upah yang layak adalah upah yang disetujui oleh kedua belah pihak. Menurut pemerintah, upah yang layak adalah upah yang sesuai dengan kebutuhan berdasarkan perhitungan KHL.

2. Peran Pemerintah dalam mengupayakan hak atas upah yang layak bagi pekerja

Untuk menjamin agar pekerja mendapatkan upah yang layak, maka pemerintah menetapkan kebijakan pengupahan yaitu kebijakan upah minimum dan kebijakan struktur dan skala upah. Dalam kebijakan upah minimum, Dinas Tenaga Kerja dan perindustrian Kota Surakarta mempunyai peran, yaitu:

a. Perhitungan Upah Minimum;

b. Mengusulkan ke Bupati/Walikota;

c. Melakukan Pengawasan;

d. Memberikan sanksi.

Selanjutnya dalam kebijakan struktur dan skala upah, Dinas Tenaga Kerja dan Perindustrian Kota Surakarta, berperan sebagai: a. Memberikan Pelatihan dan Sosialisasi mengenai Struktur dan Skala Upah;

b. Melakukan Pemantauan dan Monitoring;

c. Memberikan sanksi.

3. Hambatan dan Solusi

Hambatan yang dialami Dinas tenaga Kerja dan Perindustrian Kota Surakarta dalam melaksanakan perannya mengupayakan hak atas upah yang layak bagi pekerja adalah:

a. Kurangnya pemahaman perusahaan mengenai struktur dan skala upah;

b. Ada perusahaan yang tidak menyusun dan merasa terbebani dengan adanya struktur dan skala upah;

Dengan adanya hambatan tersebut, maka pemerintah melakukan langkah-langkah untuk menyelesaikan hambatan tersebut. Langkah-langkah tersebut yaitu:

a. Sosialisasi dan Pelatihan;

b. Memberikan Sanksi administratif kepada perusahaan yang tidak menerapkan struktur dan skala upah.

\section{Saran}

Berdasarkan hasil temuan studi dilapangan, kesimpulan, implikasi, maka peneliti dapat kemukakakn saran-saran berikut:

1. Kepada Dinas Tenaga Kerja dan Perindustrian Kota Surakarta agar melakukan pengawasan dengan sungguh-sungguh, karena 
73 Wulandari, Triana Rejekiningsih, Muh. Hendri N: peran pemerintah dalam ...

$$
\begin{aligned}
& \text { masih banyak perusahaan } \\
& \text { yang belum menyusun } \\
& \text { struktur dan skala upah; } \\
& \text { 2. Kepada pekerja di Kota } \\
& \text { Surkarta agar } \\
& \text { meningkatkan } \\
& \text { produktivitasnya } \\
& \text { pengusaha tidak keberatan } \\
& \text { untuk menaikkan upah } \\
& \text { pekerja; }
\end{aligned}
$$

Kepada pengusaha di Kota

Surakarta agar mematuhi kebijakan dan peraturan perundang-undangan untuk segera menerapkan Upah Minimum sebagai upah terendah dan menyusun struktur dan skala upah agar kesejahteraan pekerja meningkat 


\section{DAFTAR PUSTAKA}

Kalidjernih, Freddy K. 2011. Puspa Ragam Konsep dan Isu Kewarganegaraan Edisi Ketiga. Bandung: Widya Aksara Press

Sutopo, H.B. 2002. Metodologi Penelitian Kualitatif. Dasar-dasar Teoriti dan Penerapannya Dalam Penelitian. Surakarta: UNS Press.

Winarno dan Wijianto. 2010. Ilmu Kewarganegaraan dalam Konteks Pendidikan Kewarganegaraan. Surakarta: UNS Press.

Moleong, L. J. (2014). Metodologi Penelitian Kualitatif. Bandung: PT Remaja Rosdakarya.

Afrizal. 2015. Metode Penelitian Kualitatif: Sebuah Upaya Mendukung Penggunaan Penelitian Kualitatif dalam Berbagai Disiplin Ilmu. Jakarta: PT Rajagrafindo Persada.

Undang-Undang Dasar Negara Republik Indonesia Tahun 1945

Undang-Undang Nomor 13 Tahun 2003 tentang Ketenagakerjaan

Undang Undang Nomor 39 tahun 1999 tentang Hak Asasi Manusia

http://disnakerperin.surakarta.go.id/detail/berita-pasar-kerja-surakarta/78/umkkota-surakarta-tahun-2018.html http://solo.tribunnews.com/2017/10/31/nilai-umk-solo-2018-naik-jadi-rp-

1668700-serikat-pekerja-sebut-jumlahnya-tak-rasional https://economy.okezone.com/read/2017/11/02/320/1807423/ump-cuma-naik-817-buruh-minta-komponen-kebutuhan-hidup-layak-ikut-diperhitungkan 